\title{
PENGARUH KUALITAS LAYANAN TERHADAP KEPUASAN PELANGAN RESTORAN WARUNK UPNORMAL JAMBI
}

\author{
Endah Tri Kurniasih ${ }^{1}$ \\ Dosen Universitas Muhammadiyah Jambi ${ }^{1}$ \\ endah.trikurniasih@gmail.com \\ Dahli Kusuma ${ }^{2}$ \\ Mahasiswa Universitas Muhammadiyah Jambi ${ }^{2}$ \\ darilkhan88@yahoo.com \\ Ringkasan
}

\begin{abstract}
Penelitian ini bertujuan untuk mengetahui dan menganalisis apakah kualitas layanan yang terdiri atas dimensi tangible, reliability, responsiveness, assurance, dan empathy berpengaruh terhadap kepuasan pelanggan Restoran Warunk Upnormal, dan untuk mengetahui dan menganalisis variable manakah yang paling dominan berpengaruh terhadap kepuasan pelanggan Restoran Warunk Upnormal. Hasil Penelitian ini yaitu : Warung Upnormal Jambi disarankan untuk lebih meningkatkan Kualitas Layanan agar Kepuasan Pelanggan dapat terbentuk semakin kuat sehingga dapat memicu peningkatan produktivitas perusahaan. Perusahaan yang membawahi Warung Upnormal Jambi diharapkan memberikan informasi yang relevan dalam kaitannya dengan pembahasan yang diajukan demi kemajuan dan keberhasilan perusahaan. Perusahaan harusnya memperhatikan peluang-peluang pasar dari perspektif konsumen yang ada dan memanfaatkan peluang tersebut sebaik mungkin untuk lebih meningkatkan pangsa pasar.
\end{abstract}

Kata Kunci: Kualitas Layanan, Kepuasan Pelanggan

\section{PENDAHULUAN}

Bisnis Kuliner merupakan salah satu bisnis berkembang pesat dan memiliki potensi yang cukup besar. Seiring berkembang zaman kini kegiatan makan bukan lagi hanya untuk menebus rasa lapar dan haus, tetapi menjadi salah satu ajang rekreasi. Hal tersebut menjadi tantangan bagi pengusaha kuliner untuk beradaptasi mengikuti perubahan gaya hidup yang kian berkembang dengan memberikan sebuah pengalaman makan tidak biasa dan pada akhirnya menciptakan loyaritas konsumen itu sendiri.

Semakin ketatnya persaingan bisnis, menyebabkan pelanggan memiliki lebih banyak alternatif produk, harga dan kualitas yang bervariasi, sehingga pelanggan akan selalu mencari nilai yang dianggap paling tinggi dari berbagai produk. Selain produk, kualitas layanan juga memiliki hubungan yang erat dengan kepuasan pelanggan.Kualitas layanan memberikan suatu dorongan kepada pelanggan untuk menjalin ikatan hubungan yang kuat dengan perusahaan.Dalam jangka panjang ikatan seperti ini memungkinkan perusahaan untuk memahami dengan seksama harapan pelanggan serta kebutuhan mereka. 
Dengan demikian, perusahaan dapat meningkatkan kepuasan pelanggan dimana perusahaan memaksimumkan pengalaman pelanggan yang menyenangkan dan meminimumkan pengalaman pelanggan yang kurang menyenangkan. Apabila kualitas pelayanan yang diterima pelanggan lebih baik atau sama dengan yang diharapkan, maka pelanggan akan puas dan cenderung akan mencobanya kembali, begitu pula dengan sebaliknya.

Restoran Warunk Upnormal merupakan restoran yang menyajikan berbagai makanan khas anak muda zaman sekarang dan telah memiliki cabang di berbagai kota lainnya, salah satunya di Kota Jambi. Restoran ini tidak hanya menyajikan makanan khas Indonesia yang enak namun mereka menyadari bahwa perlunya kualitas layanan yang dibutuhkan untuk memuaskan para pelanggan sehingga dapat menimbulkan loyalitas pelanggan terhadap Restoran Warunk Upnormal. Restoran ini menyediakan tempat makan yang nyaman, bersih, dan rapi.Restoran Warunk Upnormal memberikan ruangan yang bebas rokok dengan fasilitas AC,TV, dan ada juga ruangan yang khusus merokok. Seluruh layanan ini ditujukan untuk kepuasan pelanggan yang notabene anak muda. Tujuan dari penelitian ini adalah: (1) untuk menganalisis kualitas layanan yang terdiri atas dimensi tangible, reliability, assurance, dan empathy berpengaruh terhadap kepuasan pelanggan Restoran Warunk Upnormal; dan (2) variabel manakah yang paling dominan berpengaruh terhadap kepuasan pelanggan di Restoran Warunk Upnormal.

\section{TINJAUAN PUSTAKA}

Kualitas adalah sebuah kata yang bagi penyedia jasa merupakan sesuatu yang harus dikerjakan dengan baik (Supranta, 2001). Dalam menentukan kualitas jasa, terdapat lima dimensi kualitas jasa sebagaimana telah dikemukakan oleh Parasuraman et.al. (1998) yaitu dimensi tangibles, reliability, responsiveness, assurance dan emphaty.

Kualitas layanan adalah hal mutlak yang harus dimiliki oleh perusahaan atau instansi yang menawarkan jasa, karena dengan kualitas layanan kepada konsumen, perusahaan atau instansi dapat mengukur tingkat kinerja yang telah dicapai. Terdapat lima dimensi kualitas layanan yang dapat digunakan melakukan evaluasi terhadap kualitas jasa menurut Valerie Zeuthaml, A. Parasuraman, dan Leonard Berry yaitu:

a. Tangible (berwujud), yaitu berupa penampilan fasilitas fisik, peralatan, pegawai, dan material yang dipasang. Dimensi ini menggambarkan wujud secara fisik dan layanan yang akan 
diterima oleh konsumen. Contohnya dalam jasa restoran, maka karyawannya memakai seragam yang rapi, jumlah meja makan, dan peralatan makanan yang lengkap.

b. Reliability (keandalan) yaitu kemampuan untuk memberikan jasa yang dijanjikan dengan handal dan akurat. Dalam arti luas,keadalan berarti bahwa perusahaan memberikan janjijanjinya tentang penyediaan, penyelesain masalah dan harga.

c. Responsiveness (daya tanggap) yaitu kesadaran dan keinginan untuk membantu pelanggan dan memberikan jasa dengan cepat. Dimensi ini menekankan pada perhatian dan ketepatan ketika berurusan dengan permintaan, pertanyaan, dan keluhan pelanggan.

d. Assurance (kepastian) yaitu pengetahuan, sopan santun dan kemampuan karyawan untuk menimbulkan kayakinan dan kepercayaan. Dimensi ini mungkin akan sangat penting pada jasa layanan yang memerlukan tingkat kepercayaan cukup tinggi dimana pelanggan akan merasa aman dan terjamin.

e. Empathy (empati) yaitu kepedulian, dan perhatiaan secara pribadi yang diberikan kepada pelanggan. Inti dari dimensi empati adalah menunjukkankepada pelanggan melalui layanan yang diberikan bahwa pelanggan ituspesial, dan kebutuhan mereka dapat dipahami.

Menurut Kotler dan Keller (2009), "Satisfaction reflects a person's judgements of a product's perceived performance (or outcome) in relationship to expectation" yang berarti kepuasan merupakan perasaan senang atau kecewa yang dihasilkan dari perbandingan performance produk terhadap ekspektasi mereka.Jika performance gagal memenuhi ekspektasi, maka pelanggan menjadi tidak puas.Jika performance sesuai dengan ekspektasi, maka pelanggan menjadi puas.Jika performance melebihi ekspektasi, maka pelanggan merasa sangat puas.

Menurut hal yang diungkapkan Zeithaml \& Bitner (2008:110) mendefinisikan kepuasan pelanggan sebagai respon pelanggan terhadap evaluasi ketidaksesuaian yang dirasakan antara harapan dan kinerja aktual jasa.Sementara menurut Dutka (dalam Melinda, 2008) terdapat tiga dimensi dalam mengukur kepuasan pelanggan secara universal yaitu

1). Attributes related to product yaitu dimensi kepuasan yang berkaitan dengan atribut dari produk seperti penetapan nilai yang didapatkan dengan harga, kemampuan produk menentukan kepuasan, benefit dari produk tersebut.

2). Attributes related to service yaitu dimensi kepuasan yang berkaitan dengan atribut dari pelayanan misalnya dengan garansi yang dijanjikan, proses pemenuhan pelayanan atau pengiriman, dan proses penyelesaian masalah yang diberikan. 
3). Attributes related to purchase yaitu dimensi kepuasan yang berkaitan dengan atribut dari keputusan untuk membeli atau tidaknya dari produsen seperti kemudahan mendapat informasi, kesopanan karyawan dan juga pengaruh reputasi perusahaan.

Kepuasan pelanggan merupakan suatu tingkatan dimana kebutuhan, keinginan dan harapandari pelanggan dapat terpenuhi yang akan mengakibatkan terjadinya pembelian ulang ataukesetiaan yang berlanjut (Band, 1991). Para pelaku usaha dapat mengetahui kepuasan dari para konsumennya melalui umpan balik yang diberikan oleh konsumen tersebut sehingga dapat menjadi masukan untuk pengembangan dan usaha dan peningkatan pelayanan kedepannya.

\section{METODE PENELITIAN}

Penelitian ini menggunakan desain penelitian kausal, penelitian kausal adalah salah satu tipe konklusif dimana mempunyai tujuan utama untuk mengetahui dan memperoleh bukti mengenai hubungan sebab akibat (malholtra 2004). Hubungan sebab akibat pada penelitian ini untuk mengungkapkan pengaruh kualitas layanan terhadap kepuasan pelanggan Restoran Warunk Upnormal.

\section{Populasi dan Sampel}

Populasi yang menjadi target dalam penelitian ini adalah konsumen yang pernah datang dan melakukan pembelian di Restoran Warunk Upnormal Jambi.Sedangkan sampeldalam penelitian ini adalah sebagian dari pelanggan yangpernah datang dan melakukan pembelian di Restoran Warunk Upnormal Jambi dalam 6 bulan terakhir.

Teknik sampel yang digunakan dalam penelitian ini adalah nonprobability sampling yaitu sampling purposive. Pada sampling puposive peneliti menarik sampel berdasarkan pertimbangan tertentu. Kriterianya adalah pelanggan yang pernah melakukan pembelian di Restoran Warunk Upnormal Jambi sebanyak lebih dari 1 kali selama 6 bulan terakhir.

\section{Metode Pengumpulan Data}

Metode pengumpulan data dalam penelitian ini adalah metode dokumentasi studi pustaka.Teknik dokumentasi digunakan untuk mengumpulkan data berupa data-data tertulis yang mengandung keterangan dan penjelasan serta pemikiran tentang fenomena yang masih actual dan sesuai dengan masalah penelitian. Teknik dokumentasi diprores dan berawal dari menghimpun dokumen, memilih-milih dokumen sesuai dengan tujuan penelitian, mencatat dan menerangkan, menafsirkan dan menghubung-hubungkan dengan fenomena lain. 


\section{PengujianRegresi LinearBerganda}

Menurut Malhotra (2004), analisa regresi linear adalah prosedur statistik untuk menganalisa hubungan antara variabel dependen dan variabel independen.Jika terdapat dua atau lebih variabel bebas maka menggunakan analisa regresi linear berganda.Dengan demikian dapat diketahui seberapa besar pengaruh antara variabel bebas terhadap variabel terikat. Menurut Malhotra (2004) rumus yang dapat digunakan sebagai perhitungan analisa regresi linear berganda adalah sebagai berikut:

$$
\mathrm{Y}=\alpha+\beta 1 \mathrm{x} 1+\beta 2 \mathrm{X} 2+\beta 3 \mathrm{X} 3+\beta 4 \mathrm{X} 4+\beta 5 \mathrm{X} 5+\mathrm{e}
$$

Keterangan:

$\mathrm{Y}=$ kepuasan pelanggan (dependen)

$\alpha=$ konstanta

$\mathrm{X} 1$ =tangible (independen)

$\mathrm{X} 2$ = reliability (independen)

$\mathrm{X} 3=$ responsiveness (independen)

$\mathrm{X} 4$ = assurance (independen)

X5 = emphaty (independen)

$\beta 1=$ koefisien regresi $\mathrm{X} 1$

$\beta 2=$ koefisien regresi $\mathrm{X} 2$

$\beta 3=$ koefisien regresi $X 3$

$\beta 4=$ koefisien regresi $\mathrm{X} 4$

$\beta 5=$ koefisien regresi $\mathrm{X} 5$

$\mathrm{e}=$ Standar of error

\section{Teknis Analisis Data}

Dalam penelitian ini, penulis menganalisis data dengan menggunakan teknik analisis regresi berganda, teknik analisis ini digunakan untuk menguji pengaruh hubungan variabel bebas $(\mathrm{X})$ dengan variabel terikat $(\mathrm{Y})$

1. Uji Normalitas Data

Uji normalitas data dilakukan dengan tujuan untuk mengetahui apakah sampel yang diambil telah memenuhi kriteria sebaran atau distribusi normal, apakah data yang terdapat dalam sampel baik variabel dependent, variabel independent atau keduanya mempunyai distribusi normal atau mendekati normal. Untuk menguji apakah distribusi data normal atau tidak dapat dilakukan dengan cara: 
a) Melihat histogram yang membandingkan antara data observasi dengan distribusi yang mendekati distribusi normal.

b) Dengan melihat Normal Probability Plot yang membandingkan distribusi kumulatif dari data sesungguhnya dengan distribusi kumulatif dari distribusi normal. Jika distribusi adalah normal maka garis yang menggambarkan data sesungguhnya akan mengikuti garis diagonalnya.

2. Uji Multikolinieritas

Uji Multikolinieritas bertujuan untuk menguji apakah model regresi ditemukan adanya korelasi antar variabel independen.Model regresi yang baik seharusnya tidak terjadi korelasi diantara variabel independen.Untuk mendeteksi ada atau tidaknya multikolonieritas didalam model regresi adalah dengan Nilai Tolerance dan Variance Inflation Factor (VIF).Kedua ukuran ini menunjukkan setiap variabel independen manakah yang dijelaskan oleh variabel bebas lainnya. Dalam pengertian sederhana setiap variabel independen menjadi variabel dependen dan diregres terhadap variabel independen lainnya. Jadi nilai Toleransi yang rendah sama dengan nilai VIF yang tinggi dan menunjukkan adanya kolenieritas yang tinggi. Nilai yang umum dipakai adalah nilai Tolerance 0,10 atau sama dengan nilai VIF diatas 10.

3. Uji Heteroskedastisitas

Uji heteroskedastisitas digunakan untuk menguji apakah dalam regresi terjadi ketidaksamaan varian nilai residual satu pengamatan ke pengamatan yang lain. Dekteksi kemungkinan adanya gejala heteroskedasitas dapat dilakukan dengan menggunakan diagram scatterpoot, dimana sumbu $\mathrm{X}$ adalah residual (SRESID) dan sumbu Y adalah nilai Y yang diprediksi (ZPRED). Jika pada grafik tidak ada pola yang jelas serta titiktitik menyebar di atas dan di bawah sumbu 0 (nol) pada sumbu Y, maka tidak terjadi hereroskedasitas dalam suatu model regresi.

4. Uji Autokorelasi

Uji Autokorelasi bertujuan menguji apakah dalam suatu model regresi linear ada korelasi antara kesalahan pengganggu pada periode $t$ dengan kesalahan pada periode $t-1$ (sebelumnya). Autokorelasi muncul karena observasi yang berurutan sepanjang waktu berkaitan satu sama lain. Masalah ini muncul karena residual (kesalahan pengganggu) tidak bebas dari satu observasi ke observasi lainnya. Hal ini sering ditemukan pada data menurut waktu atau time series karena gangguan pada seseorang individu/kelompok 
yang sama pada periode berikutnya. Ada beberapa cara yang dapat digunakan untuk mendeteksi ada atau tidaknya autokorelasi:

a) Bila nilai D-W terletak antara batas atas atau upper bound (du) dan (4-du) maka koefisien autokorelasi sama dengan nol, yang berarti tidak ada autokorelasi.

b) Bila nilai D-W lebih rendah dari batas bawah (dl), maka koefisien autokorelasi sama lebih besar nol, yang berarti ada autokorelasi positif.

c) Bila nilai DW lebih besar dari pada (4-dl), maka koefisien autokorelasi lebih kecil dari pada nol, berati ada korelasi negatif.

d) Bila nilai D-W terletak diantara batas atas (du) dan batas bawah (dl) atau DW terletak antara (4-du) dan (4-dl), maka tidak dapat disimpulkan.

\section{PEMBAHASAN}

Responden dalam penelitian ini para pengunjung Warunk Upnormal Jambi yang membeli menu-menu makanan yang ada serta kepuasan yang diterima konsumen.Jumlah responden yang diteliti atau sampel adalah sebanyak 64 orang. Jumlah kuesioner yang didistribusikan sebanyak 20 pertanyaan yang diolah dengan SPSS 23.0.dan memanfaatkan media Google Docs dalam penyebaran kuesioner.

\section{Responden Berdasarkan Jenis Kelamin}

Grafik berikut ini menunjukkan data pengunjung Warunk Upnormal Jambi yang menjadi sampel penelitian:

Grafik.1. Responden berdasarkan Jenis Kelamin

\section{Jenis Kelamin}

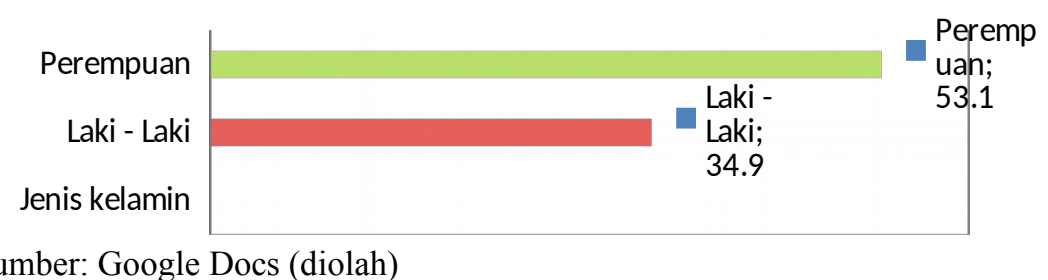

Sumber: Google Docs (diolah)

Berdasarkan Grafik.1. di atas diketahui jenis kelamin dikelompokkan menjadi laki-laki dan perempuan. Dari hasil pengolahan data yang telah dilakukan maka dapat diketahui bahwa 34 orang atau $53,1 \%$ responden adalah perempuan dan 30 orang atau 46,9\% responden adalah laki-laki. 


\section{Responden Berdasarkan Usia}

Grafik berikut ini menunjukkan data pengunjung Warunk Upnormal Jambi yang menjadi sampel penelitian berdasarkan usia:

\section{Grafik.2 Responden Berdasarkan Usia}

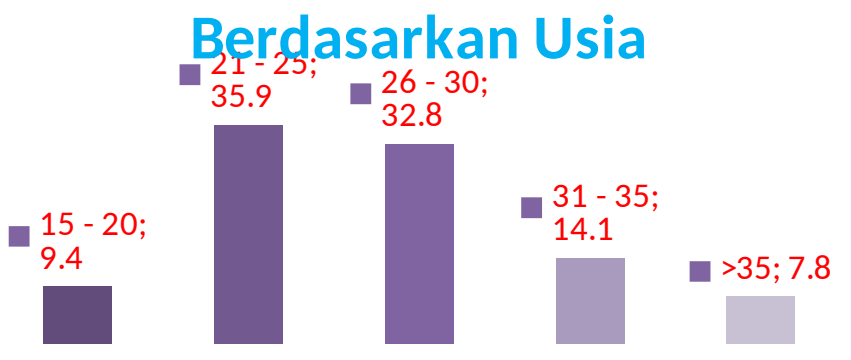

Sumber: Goog Docs (Diolah)

Dari Grafik 2 bisa dilihat bahwa pengunjung Warunk Upnormal Jambi berdasarkan usia yaitu; $<20$ tahun sebanyak9,4\%, konsumen berusia 21-25 tahun sebanyak 35,9\%dengan usia 26-30 tahun sebanyak 32,8\%. Kemudian responden yang berusia di atas 30 tahun dikategorikan menjadi 31-35 tahun yang berjumlah sebanyak 14,1\%, 36-40 tahun responden dengan jumlah terkecil berada yaitu sebanyak 7,8\%. Dari penjelasan di atas dapat kita ketahui bahwa pengunjung Warunk Upnormal ini lebih diminati oleh rentang usia antara $21-25$ tahun.

\section{Responden berdasarkan Pekerjaan}

Grafik berikut ini memperlihatkan pekerjaan para pengunjung Warunk Upnormal Jambi yang menjadi sampel penelitian:

Grafik.3. Responden berdasarkan Pekerjaan

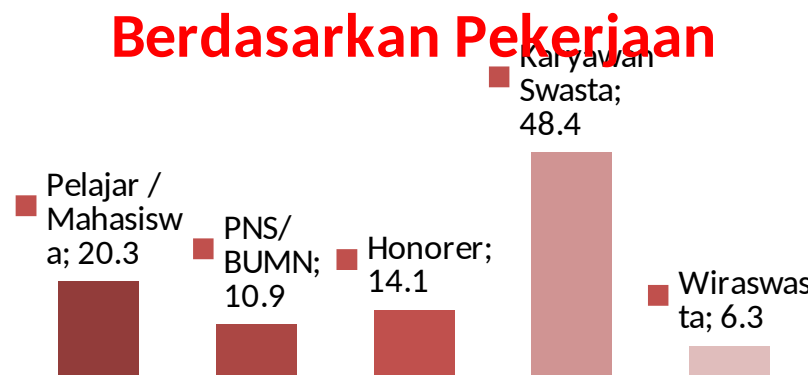

Sumber: Goog Docs (Diolah)

Berdasarkan Grafik di atas, terlihat responden didominasi oleh Karyawan Swasta yaitu sebanyak 31 atau 48,4\%. Responden pelajar/mahasiswa sebanyak 13 atau 20,3\% ,Honorer9 orang atau $14,1 \%$, pegawai negeri 7 orang atau 10,9\% Sementara sisanya sebanyak 4 orang atau $6,3 \%$ memiliki pekerjaan lain. Pekerjaan lain ini seperti wiraswasta. 


\section{Uji Validitas dan Uji Reliabilitas}

\section{Uji Validitas}

Uji validitas digunakan untuk mengetahui kelayakan butir-butir dalam suatu daftar pertanyaan dalam mendefinisikan suatu varianel. Hasil $r$ hitung dibandingkan dengan $r$ variabel dimana $\mathrm{df}=\mathrm{n}-2$ dengan signifikan 5\%. Jika $\mathrm{r}$ tabel $<\mathrm{r}$ hitung maka valid (Sujarweni, 2014).

Dengan menggunakan jumlah responden 64 maka nilai $r$ tabel dapat diperoleh melalui tabel $r$ dengan $\mathrm{df}=64-2=62$, maka $\mathrm{r}$ tabel $=0.159$. Hasil uji Validitas dapat dilihat pada tabel di bawah ini:

Tabel.1. Uji Validitas Kepuasan Pelanggan

\begin{tabular}{|c|c|c|c|}
\hline Item & r hitung & r tabel & Pernyataan \\
\hline $\begin{array}{l}\text { Apa menu yang disajikan Warunk Upnormal } \\
\text { Jambi sesuai dengan kebutuhan anda }\end{array}$ & 0.391 & 0.159 & Valid \\
\hline $\begin{array}{l}\text { ApakahWarunk Upnormal Jambi sering } \\
\text { mengadakan promo }\end{array}$ & 0.377 & 0.159 & Valid \\
\hline $\begin{array}{l}\text { Apakah karyawan sigap merespon requst } \\
\text { food and beverage yang anda pesan }\end{array}$ & 0.414 & 0.159 & Valid \\
\hline $\begin{array}{l}\text { Apakah karyawan Warunk Upnormal } \\
\text { menyapa dan tersenyum pada anda saat } \\
\text { memasuki Warunk Upnormal }\end{array}$ & 0.431 & 0.159 & Valid \\
\hline $\begin{array}{l}\text { Apakah fasilitas Warunk Upnormal Jambi } \\
\text { membuat anda nyaman }\end{array}$ & 0.416 & 0.159 & Valid \\
\hline $\begin{array}{l}\text { Sesuaikah pelayanan yang diberikan oleh } \\
\text { karyawan Warunk Upnormal dengan } \\
\text { harapan anda }\end{array}$ & 0.402 & 0.159 & Valid \\
\hline $\begin{array}{l}\text { Apakah anda sering berkunjung kembali ke } \\
\text { Warunk Upnormal Jambi }\end{array}$ & 0.334 & 0.159 & Valid \\
\hline $\begin{array}{l}\text { Apa anda ingin berkunjung kembali ke } \\
\text { Warunk Upnormal Jambi }\end{array}$ & 0.377 & 0.159 & Valid \\
\hline $\begin{array}{l}\text { Apakah anda membeli food dan beverage itu } \\
\text { karena anda mendapatkan fasilitas } \\
\text { penunjang lainnya }\end{array}$ & 0.361 & 0.159 & Valid \\
\hline $\begin{array}{l}\text { Apakah anda memperoleh manfaat yang } \\
\text { dirasakan saat berada di Warunk Upnrmal }\end{array}$ & 0.378 & 0.159 & Valid \\
\hline $\begin{array}{l}\text { Menurut anda apakah kualitas food and } \\
\text { beverage yang disajikan Warunk Upnormal } \\
\text { Jambi cukup baik }\end{array}$ & 0.392 & 0.159 & Valid \\
\hline $\begin{array}{l}\text { Apakah produk yang disajikan sesuai } \\
\text { dengan selera anda }\end{array}$ & 0.397 & 0.159 & Valid \\
\hline $\begin{array}{l}\text { Apakah menurut anda food and beverage } \\
\text { berkualitas }\end{array}$ & 0.384 & 0.159 & Valid \\
\hline $\begin{array}{l}\text { Apakah kualitas layanan yang diberikan } \\
\text { karyawan cukup baik }\end{array}$ & 0.397 & 0.159 & Valid \\
\hline Apakah karyawan Warunk Upnormal pernah & 0.347 & 0.159 & Valid \\
\hline
\end{tabular}


mensosialisasikan kepada anda bagaimana cara anda mengajukan complain

Apakah mudah untuk melakukan complain di Warunk Upnormal Jambi

$0.369 \quad 0.159 \quad$ Valid

Sebagai pelanggan, tahukah anda bagaimana cara mengajukan complain

$0.378 \quad 0.159 \quad$ Valid

Apa menurut anda, saat karyawan menerima keluhan dan saran dari pelanggan

0.386

0.159

Valid

meneriman dengan baik

Apakah Warunk Upnormal menjamin

garansi food and beverage yang anda pesan

ketika mengalami unconditional situasi

$\begin{array}{lll}0.365 & 0.159 \quad \text { Valid }\end{array}$

seperti minuman ata makanan yang tumpah

Apakah karyawan Upnormal

memberitahukan tentang garansi produk

yang anda beli

Sumber : SPSS 23.0 (diolah)

\section{Uji Reliabilitas}

Reliabilitas adalah sebuah ukuran kestabilan dan konsistensi dari jawaban responden terhadap masalah yang berkaitan dengan setiap butir pertanyaan.Jika Alpha Cronbach $>0.60$ maka pernyataan dikatakan reliabel (Sujarweni, 2014). Tabel berikut ini menunjukkan hasil uji reliabilitas:

Uji Reliabilitas

Reliability Statistics

\begin{tabular}{|r|rr|}
\hline \multicolumn{2}{|l|}{ Cronbach's Alpha ${ }^{\mathrm{a}}$} & \multicolumn{1}{|c|}{ N of Items } \\
\hline
\end{tabular}

Sumber: SPSS 23.0 (diolah)

Tabel diatas memperlihatkan bahwa nilai Alpha Cronbach dari setiap variabel 0.81 , jadi disimpulkan bahwa semua variabel dalam penelitian ini reliabel.

Analisis Regresi Linear Berganda (Uji Korelasi (r))

Tabel.2. Uji Korelasi (r)

Model Summary

\begin{tabular}{|l|r|r|r|r|}
\hline Model & \multicolumn{1}{|c|}{$\mathrm{R}$} & \multicolumn{1}{|c|}{ R Square } & Adjusted R Square & $\begin{array}{l}\text { Std. Error of the } \\
\text { Estimate }\end{array}$ \\
\hline 1 & $.470^{\mathrm{a}}$ & .221 & .178 & 5.365 \\
\hline
\end{tabular}

a. Predictors: (Constant), Answer 
Dari output di atas diketahui bahwa nilai koefisien determinasi atau R Square adalah sebesar 0.221 , yang berasal dari pengkuadratan nilai koefisien korelasi atau $\mathrm{R}$ yaitu $0.470 \mathrm{x}$ $0.470=0.221$

Besarnya angka koefisien determinasi (R Square) adalah 0.221 atau sama dengan 22,1\% yang berarti bahwa variabel Kualitas Layanan (X) berpengaruh terhadap variabel Kepuasan Pelanggan (Y) sebesar 22,1\%. Sedangkan sisanya 77,9\% dipengaruhi oleh variabel yang tidak dijelaskan dalam penelitian ini.

\section{Koefisien Determinasi}

Koefisien Determinasi

ANOVA $^{\mathrm{b}}$

\begin{tabular}{|ll|r|r|r|r|r|}
\hline Model & & Sum of Squares & Df & Mean Square & F & \multicolumn{1}{c|}{ Sig. } \\
\hline 1 & Regression & 146.930 & 1 & 146.930 & 5.105 & $.036^{\mathrm{a}}$ \\
& Residual & 518.070 & 18 & 28.782 & & \\
& Total & 665.000 & 19 & & & \\
\end{tabular}

a. Predictors: (Constant), Answer

b. Dependent Variable: Question

Berdasarkan table ANOVA diketahui bahwa nilai Sig. dalam uji $\mathrm{F}$ adalah sebesar 0,036, dimana $\leq 0.05$, karenanya dapat disimpulkan bahwa dalam uji F, Kualitas Layanan (X) secara simultan dapat mempengaruhi Kepuasan Pelanggan (Y). dengan demikian maka koefisien determinasi dapat terpenuhi.

\section{Uji Hipotesis}

\section{Uji Parsial ( uji t )}

Untuk menentukan jawaban atas hipotesis, maka kita akan melihat tingkat signifikan dari $\mathrm{T}$ hitung berbanding $\mathrm{T}$ tabel. Untuk mengetahui pengaruh $\mathrm{X}$ dan $\mathrm{Y}$, dapat dilihat melalui dua cara. Cara yang pertama adalah dengan melihat nilai signifikan.Jika nilai signifikan $>0.05$ maka tidak ada pengaruh antara $\mathrm{X}$ dan $\mathrm{Y}$. Dan jika nilai signifikan $<0.05$ maka terdapat pengaruh antara $\mathrm{X}$ dan $\mathrm{Y}$.

Cara kedua adalah dengan membandingkan ( $\mathrm{t}$ hitung $)$ dan $(\mathrm{t}$ tabel $)$. Jika $\mathrm{t}$ hitung $<\mathrm{t}$ tabel maka tidak ada pengaruh antara $X$ dan $Y$. Dan jika $t$ hitung $>t$ tabel maka terdapat pengaruh antara $\mathrm{X}$ dan $\mathrm{Y}$.

Berikut ini adalah jawaban atas Uji Parsial (t) dengan SPSS 23.0 version: 


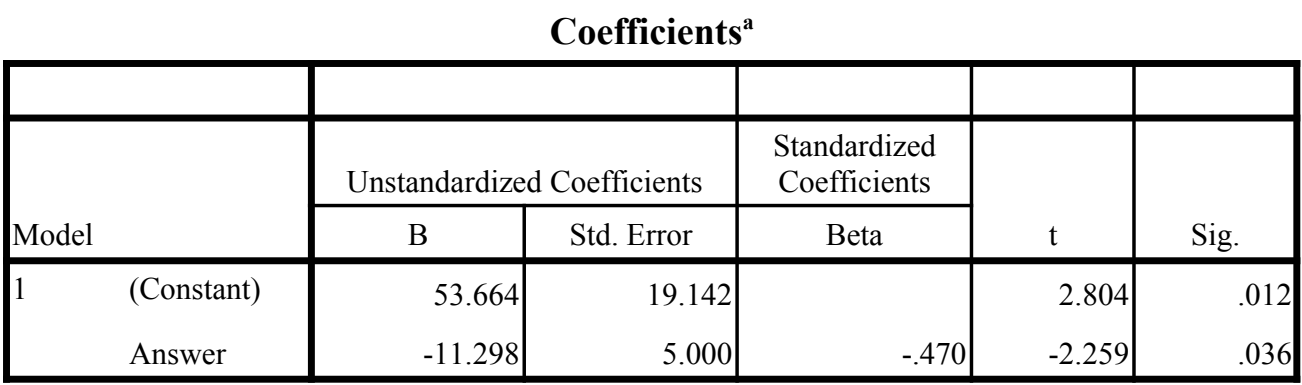

a. Dependent Variable: Question

Berdasarkan table coefficients diatas diketahui bahwa nilai signifikansi (Sig) variabel Kualitas Layanan (X) sebesar 0.036. Karena nilai Sig $.0 .036 \leq 0.05$ maka dapat disimpulkan bahwa H1 diterima.Artinya terdapat pengaruh Kualitas Layanan (X) terhadap Kepuasan Pelanggan (Y).

Persamaan regresi dari penelitian ini adalah $\mathbf{Y}=\mathbf{5 3 . 6 4 - 1 1 1 2 9 8 X}+\mathbf{e}$. Konstanta sebesar53.664 memberikan pengertian bahwa jika variabel Brand image sama dengan nol (0) maka keputusan pembelian sebesar 53.664. Jika Variabel X (Kualitas Layanan) naik 1 angka, maka keputusan pembelian akan naik sebesar 11.298dengan asumsi variabel lain konstan. Karena koefisien regresinya adalah positif, hal ini dapat diartikan apabila variabel Kualitas Layanan semakin baik, maka Kepuasan Pelangganakan naik.

\section{Variabel Kualitas Layanan terhadap Kepuasan Pelanggan}

Coefficients $^{\mathrm{a}}$

\begin{tabular}{|c|c|c|c|c|c|c|}
\hline \multirow{2}{*}{\multicolumn{2}{|c|}{ Model }} & \multicolumn{2}{|c|}{ Unstandardized Coefficients } & \multirow{2}{*}{$\frac{\begin{array}{c}\text { Standardized } \\
\text { Coefficients }\end{array}}{\text { Beta }}$} & \multirow[b]{2}{*}{$\mathrm{T}$} & \multirow[b]{2}{*}{ Sig. } \\
\hline & & $\mathrm{B}$ & Std. Error & & & \\
\hline \multirow[t]{2}{*}{1} & (Constant) & 53.664 & 19.142 & & 2.804 & .012 \\
\hline & Answer & -11.298 & 5.000 & -.470 & -2.259 & .036 \\
\hline
\end{tabular}

a. Dependent Variable: Question

Sumber: SPSS 23.0 (diolah)

Berdasarkan tabel diatas, didapat nilai signifikan sebesar 0.012 , dimana nilai ini $<0.05$ maka Ho ditolak,Artinya bahwa ada pengaruh antara Variable (Question) danConstant (Answer) terhadap keputusan pembelian menu makanan Warunk Upnormal Jambi dalam penelitian.

Sementara berdasarkan $\mathrm{t}$ hitung, didapat nilai sebesar 2.804. Nilai $\mathrm{t}$ hitung ini dibandingkan dengan nilai $\mathrm{t}$ tabel $=1.988$. Maka untuk $\mathrm{t}$ hitung $>\mathrm{t}$ tabel yaitu $2.804>1.988$ artinya $\mathrm{H}_{\mathrm{a}}: \mathrm{b} \neq$ diterima atau terdapat pengaruh antara variabel Answer terhadap keputusan pembelian menu Warunk Upnormal Jambi.

\section{KESIMPULAN}


Berdasarkan hasil analisis dan pembahasan maka dapat disajikan beberapa kesimpulan yaitu sebagai berikut :

1) Berdasarkan hasil analisis menggunakan SPSS 23.0 Version dari kuesioner yang penulis lakukan terhadap 64 responden yang berpartisipasi dalam mengisi kuesioner tersebut, bahwa Kualitas Layanan (X) berpengaruh secara signifikan terhadap Kepuasan pelanggan (Y). Dimana dapat dilihat bahwa dengan adanya Kepuasan Pelanggan Warunk Upnormal Jambimemiliki nilai sig $=0,036<0,05$. Hal ini menunjukkan bahwa $\mathrm{X}$ berpengaruh signifikan terhadap Y.

2) Koefisien korelasi ganda $(\mathrm{R})=0,221$ yang berarti bahwa variable Kualitas Layanan (X)berpengaruh terhadap Kepuasan Pelanggan (Y)Warunk Upnormal Jambi. Artinya Kualitas Layanan dapat mempengaruhi Kepuasan Pelanggan sebesar 22,1\% sedangkan $77,9 \%$ dipengaruhi oleh variabel lainnya di luar penelitian ini.

3) Dengan melihat ketatnya persaingan dalam bisnis Kuliner maka salah satu upaya yang dilakukan oleh Warung Upnormal adalah dengan memperhatikan Tingkat Kepuasan pelanggan yang melekat pada menu - menu yg ditawarkan oleh Warunk Upnormal Jambi. Saran

Dari kesimpulan yang telah dikemukakan, dapat disajikan beberapa saran-saran yaitu sebagai berikut :

1) Disarankan agar Warung Upnormal Jambi lebih meningkatkan Kualitas Layanan agar Kepuasan Pelanggandapat terbentuk semakin kuat sehingga dapat memicu peningkatan produktivitas perusahaan.

2) Perusahaan yang membawahi Warung Upnormal Jambi diharapkan memberikan informasi yang relevan dalam kaitannya dengan pembahasan yang diajukan demi kemajuan dan keberhasilan perusahaan.

3) Perusahaan harusnya memperhatikan peluang-peluang pasar dari perspektif konsumen yang ada dan memanfaatkan peluang tersebut sebaik mungkin untuk lebih meningkatkan pangsa pasar.

\section{DAFTAR PUSTAKA}

Arikunto, suharsimi. 2006. Prosedur penelitian suatu pendekatanpraktik, Jakarta :rineka cipta.

Bates, John E.G., Douglas Hoffman, 1999. Managingservicesmarketing: Text and readings. Orlando : The Dryden Press Harcourt Brace College Publisher. 
ET Kurniasih, Pengaruh Service Quality Terhadap Loyalitas Konsumen Jurnal Ilmiah Ekotrans 15 (LPPM Universitas Ekasakti Padang), 99 - 109.

Green, S.B. 1991. How Many Subjects Does It Take To Do a RegressionAnalysis? Multivariate Behavioral Research, 26, 499-510.

Ghozali, Imam. 2007. Aplikasi Analisis Multivariat dengan Program.

SPSS. Badan Penerbit Universitas Diponegoro, Semarang.

Kotler, Philip. 2003. Marketing insights from A to Z. New York: JohnWiley \& Sons, Inc.

Kotler, Philip. 2005. Manajemen Pemasaran Jilid 1 (11th ed.)(Benyamin Molan, Penerjemah). Jakarta: PT. Indeks.

Kotler, Philip \& Keller, Kevin Lanne. 2009. Marketing management.13th Edition. New Jersey: Prentice Hall.

Lovelock, Christopher H., Patterson, Paul G., \& Walker, Rhett H. 2001.Service marketing: An Asia-Pacific Perspective (2nd ed.). Sydney:Prentice Hall.

Lovelock, Christopher \& Jochen Wirtz. 2004. Services marketing fifthedition people, technology, strategy. New York: Pearson.

Lupiyoadi, R \& Hamdani, A. 2006. Manajemen Pemasaran Jasa.Jakarta: Salemba Empat. 